\title{
THE ECONOMICS OF SPRAY IRRIGATION
}

\author{
By J. M. MILLER, Agricultural Economist, \\ Department of Agriculture, Hamilton
}

I can speak with any authority only of spray irrigation as applied to dairy farms in the Auckland Province, with some side references to results in other parts of New Zealand and in Australia; and I want to try to show that pasture irrigation in the Auckland Province as a general rule is neither economic nor profitable; in a few special cases it is economic; and in still fewer, profitable. By "economic" I mean as an aid to efficiency; and by "profitable" I mean as disclosed by cost accountancy. Other people use the terms "economic", "profitable", "payable", and "worthwhile" indiscriminately in reports from which I shall quote.

Taking the general rule, where it is neither economic nor profitable, and therefore is inadvisable: It is inadvisable on factorysupply dairy farms that produce less than 250lb. of butterfat per acre. This is the efficiency standard. Now, the mean annual production in the South Auckland district is about 185lb. per acre, and South Auckland is more highly developed than the other Dairy Board districts in the province, so the implication is that most dairy farms produce less than $250 \mathrm{lb}$. of butterfat per acre, and therefore come within the general rule. 1'11 say more about it later.

Taking the special cases: Irrigation is economic on townsupply dairy farms if it raises milk production at the lowest months of the year-late summer and winter-on which the quota is based. The quota is the maximum quantity on which the town-supply price is payable; anything surplus to the quota must be sold at the factory price. This was pointed out by $\mathrm{Mr}$ du Faur at Ruakura Farmers' Week in 1954; and as an example he added that "a lift in quota of a gallon a day means an extra $£ 9$ to $£ 10$ per year above the return per gallon on a factorysupply farm." "Irrigation does this," he said, "by enabling a townsupply farmer to have feed available when the cows calve in autumn and saves using valuable winter feed for the maintenance of summer production." 
One of the irrigation firms is using a similar example from lower Manawatu in its current advertising: the man carries 50 head of stock on 47 acres and endeavours to have 25 cows in milk at all times; from February to May he carries all the stock on 12 acres of irrigated pasture; and the remainder of the farm, having been spelled, comes away very well after the autumn rains, and is used for winter feeding. So you see that in this case even if the irrigation itself were not profitable it could have profitable consequences, and would thus be economic.

To me, a significant aspect of this example is the relationship between the area irrigated and the number of cows in milk12 acres for about 25 cows. This is a ratio of approximately 1 to 2 , and is much closer than that recommended by Rukuhia, which is 1 to 5 . If I now go on to a case where the ratio is even closer-2 to 3 -and the irrigation is undoubtedly profitable, you will see what I am getting at. I refer to the well-publicised farm of 30 acres on the bank of the filthy Waikato River at Horotiu, not far from here, where 20 acres are irrigated and 31 cows are milked. It is a factory-supply farm and its seasonal butterfat production is about $12,000 \mathrm{lb}$., or $400 \mathrm{lb}$. per acre. This is a remarkable achievement. The owner has been irrigating since the 1953-54 season, which was a bad drought year, when he produced $11,000 \mathrm{lb}$. Irrigation here is such a large factor in management that its costs and returns would be readily apparent in the farm accounts, and after four seasons there is no doubt as to its profitability. But what I must point out, for the sake of my main argument, is that in the 1952-53 season, before irrigation, the farm produced $9300 \mathrm{lb}$. of butterfat from 30 cows, or $310 \mathrm{lb}$. per acre.

My colleague, Mr Tocker of Christchurch, has provided another unusual example that combines in an exaggerated degree three of the factors that I have been discussing, namely, town-supply milk, the small farm, and the relatively large area irrigated. "This farm," he says, "is of 40 acres and the soil is variable with patches of pure sand. A stream almost encircles the farm and enables the whole area to be irrigated with only 10 chain of sprayline. Prior to irrigation only 12 cows were milked and the total stock carried was 17 head. Spray irrigation was started in the 1955-56 season, when a total drought was experienced for three months, and 18 cows were milked. The following season, which was very dry in January and February, 22 cows were milked. Milk production for the three seasons was 12,460 gallons, 13,270 gallons, and 15,500 gallons." He then gives a costing for the third season. "For the two months, January and February 1957, when 
irrigation was necessary the plant was operating 414 hours at a total cost of $£ 110$. At Is. $9 \mathrm{~d}$. per gallon, the summer price for milk, the $£ 110$ represents 1260 gallons. The increased production due to irrigation was 3040 gallons; thus 1780 gallons can be assumed to be profit, which at 1 s. $9 \mathrm{~d}$. per gallons is $£ 156$. This is a return on the capital invested $(\mathfrak{f 5 0 )}$ ) of nearly 20 per cent., or one-fifth of the total outlay recouped in one year after paying all operating charges." My only comment is that if we in the Waikato want grass in January we have to start watering in October.

Finally, an example from Australia, from the Victorian* Department of Agriculture's dairy farm management competition: A previous State championship winner, who "adopts each new practice only after careful calculation of the probable economic outcome," and "was one of the early farmers in Victoria to use the electric fence for strip grazing, first to make better use of feed in the spring and so save a greater area for silage making, and later to ration autumn-saved pastures in which HI ryegrass was a prominent species," "has since brought spray irrigation into his programme," and "is able to go through the summer without -feeding-out silage" to-the milkers, though he still-feeds-it out to the dry stock. He farms 124 acres, and irrigates 40 acres thoroughly, and in 1955-56 milked 58 cows-again a ratio of about two acres irrigated to three cows milked. The report concludes that the eventual carrying capacity is likely to be 80 milkers, which would mean an irrigation ratio of one to two.

My other motive for introducing an Australian example is to illustrate our inclination to think that, however controversial the subject may be in New Zealand, pasture irrigation is no doubt economic or profitable in Australia, because the climate is so much hotter and drier there. This view is apparently fallacious. For instance, the South Australian Department of Agriculture reports that a recent survey of pasture irrigation on dairy farms shows that it "can be a worthwhile proposition" but "is not profitable in every case." The words "can be" are underlined. Eight farms were surveyed, but only the highest, the lowest, and the average costs are published. The number to which the "can be" applies is not stated. 1 suspect it is not many. In one of our own reports, to which I shall refer later, the "can be" is inferred from one out of 13 .

Another review of the subject was published last year by the Bank of New South Wales in Sydney, "as a contribution to the task of improving productivity of Australian primary industry."

* Journal of Agriculture, June 1957, p. 344

$\dagger$ Journal of Agriculture. July 19.57, p. 538 . 
The compiler said he found it "virtually impossible to get exact operating costs for spray irrigation on Australian farms," and wrote in the foreword that "many more farmers will need to maintain better records if the economics of spray irrigation are to be more adequately assessed." He advises the would-be irrigator first to see the local Agricultural Officer and then to obtain plans and quotations from at least two commercial suppliers, and finally to have the suggestions checked with a Government Department. In this way the "risk of over-selling on the part of the supplier and of excessive caution on the part of a Government Department" are played off. On the whole, though, the compiler inclines to the view that pasture irrigation "can be valuable even in good years"; it is used, he points out, "in many parts of New Zealand, despite the higher and more regular rainfall compared with Australia"; but to illustrate the remark he shows a photo of a medium pressure sprayline operating on pasture at Alexandra, Central Otago, where the mean annual rainfall is about 12 in. The choice of this particular photo was no doubt an accident, but it lets me suggest to the compiler that if he were to investigate the relationship between the practice in New Zealand and in Australia he might find the resemblances to be greater than the differences, and the practice itself to be more closely related to business enterprise than to grassland farming.

However, one point of difference in New Zealand has been that the would-be irrigator had no recourse to disinterested advice until enough of his fellow-farmers had pioneered the practice. The reason for this is too delicate for me to go into, and all I will say is that it was not possible to play off against the excessive caution of a Government Department the risk of being over-sold by a commercial supplier, as the other man said. My Fields Superintendent, $\mathrm{Mr}$ Bell, was critical of the practice on the grounds that one acre of irrigated grass per 5 cows milked was not enough, but he did the calculation by some rapid kind of mental arithmetic that he was not able to explain convincingly. Anyway, in August $195 \mathrm{I}$, after a number of ordinary farmers had been irrigating for their first season, our then head economist, Dr Ojala, instructed me to make an inquiry into the results in the Waikato. The firms gave me the names of 26 users, 17 of them in the Waikato proper, and I visited these 17 in January 1952, just after the dry weather had set in that season. Few plants were operating, partly because feed was still adequate on the heavier land, and partly because of the delayed hay harvest. I selected four for investigation at the end of their second season; two of these were watered from wells and two from boundary 
streams, and the areas irrigated were flat sandy loams of the Horotiu type.

The first thing was to find out what effect the irrigation had had on butterfat production. Obviously it can affect only the dry end of the season. I got their monthly factory figures for four seasons, two before and two after, and calculated the percentage produced after New Year in each season. I then compared these percentages with the corresponding intakes at a local factory in the respective districts. Although the after-New Year percentages of both farms and factories fluctuated appreciably from season to season-as much as $8 \frac{3}{4}$ points-the mean difference between any particular farm and its factory was remarkably small both before and after irrigation-not more than $1 \frac{1}{2}$ points. One farm showed a gain of about one point on its factory for the two irrigation seasons combined, representing 190lb. of butterfat; but the two others showed small losses.

The fourth farm finished the two irrigation years 1000lb. of butterfat down on its two previous years; its calving dates had slipped badly, and it is not included in my remarks about percentage differences. The other three together produced 12,300lb. of butterfat more in their irrigation than in the two years previous, $28001 \mathrm{~b}$. of which were produced in the after-New Year periods. There was a tendency among the farmers to attribute all of this large gain to irrigation, in spite of the marked improvement in the climate and in spite of the fact that they had all begun to use potash in their topdressing. Butterfat production per acre in the final season was 202, 19 1,182, and 166lb. respectively.

Only one of the farmers had kept exact running costs. The plant cost $£ 800$; he milked 120 cows and watered 25 acres. The fuel, oil, and repairs were $£ 35$ per year; depreciation at $7 \frac{1}{2}$ per cent, on the diminishing value $\mathfrak{£ 5 4}$ per year, and interest at 41 per cent. on the investment $£ 36$ per year, a total of $£ 125$, equivalent to $830 \mathrm{lb}$. of butterfat at $3 \mathrm{~s}$. per $\mathrm{lb}$. or $7501 \mathrm{~b}$. at $3 \mathrm{~s}$. $4 \mathrm{~d}$. per lb. To break even over the two seasons would have needed about $1600 \mathrm{lb}$. of butterfat extra in the January-to-May periods whereas what was produced was 937lb. extra, and none of that was positively due to irrigation. In extenuation, I must say that the $£ 125$ per year would have been partly offset by income tax remissions, but we do not know what his tax rate was. Furthermore, he made no silage during the two seasons, but he did a lot of winter cropping and pasture renovation and leased another paddock from neighbours. And so on. The cost question is open to endless argument, unless the profit is large enough to put it beyond argument. 
The result of this survey was reported to the 1953 meeting of the Animal Production Society by Mr Noble of the Rukuhia Soil Research Station, from where it got into the press and caused a small stir. My Fields Superintendent then wrote to his Instructors, asking them to send to me for analysis the butterfat figures of any of their clients who were irrigating and who would like an analysis. None has yet done so. The reason, I think, is that people who irrigate in the Auckland Province are generally not people who consult their Instructor, but I am not sure about this.

In 1955 my Auckland colleague Mr McCarthy investigated the efficacy of spray plants in Northland, using the same method of analysis. He found 13 farms where monthly butterfat figures for two seasons before and after irrigation were available, and expressed some of his results as averages. The average area irrigated was one acre for 3.1 cows, and the average annual cost (assuming 1200 hours' running) was $£ 121$, equivalent to $809 \mathrm{lb}$. of butterfat at $3 \mathrm{~s}$. per $\mathrm{lb}$. The actual costs ranged from $6301 \mathrm{~b}$. to $1198 \mathrm{lb}$. butterfat equivalent. Of the $\mathrm{I} 3 \mathrm{farms}$, eight had a positive result in both seasons combined, and two of these eight made enough to cover operating costs in one season but not both, and one made a profit in each season amounting to about half the operating cost, which in its case was $£ 147$ per year. The season 1953-54 was a bad drought year, and 1954-55 somewhat better, and these were the seasons usually, though not necessarily, covered by the survey.

$\mathrm{Mr}$ McCarthy's conclusion, as I hinted previously, is that irrigation can be economic, but he has since written to me from Iowa State College, where he is "doing a Fulbright", saying that he is not satisfied with the method of analysis, since it is too crude. This is true, since the negative answers it may give indicate that if water is the only factor influencing summer butterfat production, it sometimes has the opposite effect to the one intended. This is extremely unlikely, but not impossible; as a matter of interest, it happened at Ruakura last summer, in their first trial with dairy farm irrigation. The water came from a bore and had an unpleasant iron flavour. The cows did not like the grass it produced; their milk flow dropped, but came up again when they were put on to other feed.

But a more likely explanation of negative answers is that there is some influence exerted by the spring that is felt later in the season. Factory intake figures show that bad dairy seasons tend to have poor springs as well as bad summers. This influence may be exerted through the level of nutrition of the herd in the "pinch month", September, and may be related to the rainfall 
and/or temperature at that time or earlier. Dr Hilgendorf at Lincoln College long ago found a positive relationship between the rainfall in October and the subsequent wheat yield. But this is by the way. Mr McCarthy is looking into it.

Far more significant in the seasonal production graphs is the long-term precession of the lactation curve. Thirty or forty years ago the factory-intake reached its maximum about Christmas time; now it reaches it about the end of October. This is the result of early calving, winter calving. For instance, this year there were no fewer than 87,000 bobby calves killed at Horotiu in July, our middle winter month. The result is that when the dry weather starts in January the herd is near the end of its milk flush and a drought has less effect on the season's output than formerly. But conversely, so does the provision of summer feed.

You remember I said at the beginning that production in the South Auckland district in the last five seasons has varied between $195 \mathrm{lb}$. and $175 \mathrm{lb}$. of butterfat per acre, a range of $201 \mathrm{~b}$. per acre. Some of this, say $4 \mathrm{lb}$, occurred in the spring and early summer, leaving 16lb. as the variation after New Year. This $16 \mathrm{lb}$. represents a fluctuation of $8 \mathrm{lb}$. about the mean. In other words, if irrigation were to make every season as good as the best, and if every farmer irrigated, and if every farmer were an ordinary farmer, he could expect to get another $8 \mathrm{lb}$. of butterfat per acre, or $800 \mathrm{lb}$. from 100 acres. As we have found, $800 \mathrm{lb}$. of butterfat is too close to the cost-equivalent of irrigation to give a profit on ordinary factory supply farms.

But hardly any farmer has both the labour and the water for intensive irrigation farming, and so the general economic implication of the practice is at present negligible. The present need of the dairy industry is for low-cost efficiency; and in regard to summer feeding there are two other interesting innovations that are getting attention. One is the application of machine power to the cutting and handling of ripe silage when it is fed out; and the other is sub-surface grass seeding after a crop. The concept of lack of water as having set an absolute bar to dairy farming progress away back in 1932-the concept on which the irrigation campaign was based-is erroneous.

\section{DISCUSSION}

Dr Annett claimed that the paper lacked evidence to support statements made against the use of spray irrigation, and he quoted his own farm where in only one year out of nine did spray irrigation not pay. 
Q. Was the extra grass produced by irrigation used efficiently by increasing stock numbers or in other ways.

A. The utilisation was not efficient in many instances. I think that the farmer who cannot produce more than $180 \mathrm{lb}$. butterfat per acre without irrigation is not efficient, and he should be improving other management practices before attempting irrigation.

Mr Hopewell said that he believed worthwhile increases could be obtained by irrigation although evidence was still scanty. Problem of utilising and managing the pasture was being investigated.

Mr Scott pointed out that it was difficult to obtain adequate economic data from farmers using spray irrigation plants and the evidence to date indicated that only on town milk supply farms was the practice economic. However with more adequate data a different picture may emerge. 